\title{
STUDENTS' ABILITY IN ANALYZING AMBIGUOUS PERSONAL REFERENCE IN WOMEN'S MURDER CLUB: THE TRIAL NOVEL
}

\author{
Masykur Rauf \\ Universitas Islam Negeri Alauddin Makassar \\ masykur.rauf@uin-alauddin.ac.id \\ Reski Amanda \\ Universitas Islam Negeri Alauddin Makassar \\ masykur.rauf@uin-alauddin.ac.id
}

\begin{abstract}
This research discussed students' ability in analysing ambiguous reference in written text. The objectives of this research were to find out students' ability and the way of the seventh-semester students of English and Literature Department (2016) in analysing the given extracts. The researchers used quantitative and qualitative methods for collecting and analysing data. The data source was the seventh-semester students of English and Literature Department (2016). The researchers used paper test (close-ended and open-ended question) as the instrument to get the data. As the procedure of collecting data, the researchers assessed the students and gave instruction to answer the test. The researchers then collected the paper after the students answered the tests. The researchers used Halliday and Hasan's reference theory which focusing on personal reference. On preliminary research, the researchers found that 1 student possessed excellent ability, 2 students got good ability, 5 students belonged to fair ability, and 2 students obtained weak ability. As the conclusion, the seventhsemester student of English and Literature Department (2016) had fair ability (67.09) in analysing ambiguous personal references. It was proved by their mean score through the paper test (multiple choice). And the researchers also concluded that analysed the given extracts by 3 ways. Those were by the context, good sense, and guessing. It was proved by their answers got through open-ended questionnaire.
\end{abstract}

Keywords: Students’ Ability, Ambiguous Reference, Personal Pronoun.

\section{A. INTRODUCTION}

$\mathrm{E}$ nglish and Literature students read texts such as English novels in their leisure. Novel is one of the favourite literature work for the students to enjoy, but it is not rare when students get struggle in identifying the antecedents of some reference items in what they read (novel). The novel's writer knows who or where he is referring to when he is writing, so he will not simply notice that he puts an ambiguous reference. An ambiguous personal pronoun (personal reference) occurs when there are more than one possible antecedents exist. It is stated by Stone (2016:1) that a pronoun takes the place of a noun, but a pronoun must always clearly refer to its antecedent, that is the noun which the pronoun replaces. If the antecedent is unclear, then the sentence will be unclear as well.

Students have been learning personal reference (called as personal pronoun in most of schools) since elementary school and even the college students learn about this subject, but it has never been explained that caused big impact if the reader refers to incorrect antecedent caused by an ambiguous reference item in written text. If the reader gets an incorrect antecedent of the reference item in reading a novel, it will affect the perception of the reader so that misreference and misunderstanding about the story will occur. Nuttal in Puspita (2017:12) categorizes that there are five aspects considered as difficulties often faced by students in understanding a text. One of the difficulty is identifying references. 


\section{Volume 6, Number 02, December 2020}

Pronoun error and ambiguous pronoun are different; pronoun error is when the reference does not match with the antecedent or breaks the pronoun agreements. The reference and its antecedent are already matched in ambiguous reference; the problem is that the reference can be referred to more than one antecedents.

There is also hadith related to the ambiguity in Islam. In the authority of Abu 'Abdullah alNu'man bin Bashir (May Allah SW'T be pleased with him) who said:

Translation: "That which is lawful is clear and that which is unlawful is clear and between the two of them are doubtful (or ambiguous) matters about which not many people are knowledgeable. Thus, he who avoids these doubtful matters certainly clears himself in regard to his religion and his honor. But he who falls into the doubtful matters falls into that which is unlawful like the shepherd who pastures around a sanctuary, all but grazing therein. Verily every king has a sanctuary and Allah's sanctuary is His prohibition." (Almath, 1995:212)

Based on that hadith, Nawawiy (Hadith Commentary, 2014) argues that human affairs are divided into three categories. First, there are cases where the halalness is very clear and not vague anymore; such as bread, fruits, oil, and other foods. Also, clearly halal actions, such as speaking, seeing, walking, and other deeds that are clearly halal, and there is not the slightest doubt. Second, there are also cases that are clearly haram. For instance, alcohol, pork, carcass, and urine. Similarly, adultery, lying, and harassment. Third, there are also vague cases that are not yet clear whether it is halal or haram. Therefore, many people do not know these cases, and they also do not understand their legal status. (Nawawiy, Syarah Al-Nawawiy 'Ala Sahih Muslim, Juz 11/27).

"Doubtful thing" or "ambiguous" in this hadith talks about something that is not known whether it is halal or haram. Based on the hadith and Nawawiy's argument, the researchers relate them to the research topic that the researchers conducted. The researchers concluded that if Muslims are ordered to avoid something ambiguous in its law because it plunged them into something haram, the same thing can happen in writing.

Ambiguous word in the written text could be big trouble for the reader to catch what the writer of the text meant. Among various studies that can be conducted to shape the interpretation of literary work, the researchers put his interest in students' ability. He is interested in this study because he wants to test the ability of the students if they find ambiguous pronoun in written text. Further, ambiguous reference can be shaped into different interpretations by different readers or they will shape the same interpretation. Considering that reason, the researchers has the initiative to conduct a research entitled Students' Ability in Analysing Ambiguous Personal Reference in “Women’s Murder Club: The Trial” Novel by James Patterson to know the students' ability towards ambiguous personal references in the novel. 
Based on the background above, the researchers formulated the research questions as follow: How is the ability of the seventh-semester students of English and Literature Department batch 2016 in analyzing the antecedents of ambiguous personal references in Women's Murder Club: The Trial novel by James Patterson? and How do the seventh-semester students of English and Literature Department batch 2016 analyze ambiguous personal references in Women's Murder Club: The Trial novel by James Patterson?. This research was aimed to find out students' ability in analyzing ambiguous personal reference in Women's Murder Club: The Trial novel by James Patterson. The researchers limited the topic of his research to analyze only one of three reference types which are classified by Halliday and Hasan (1976:43-57) that is personal reference (subject, objective, and adjective pronoun).

\section{B. REVIEW OF LITERATURE}

Some previous findings that support and contribute to the topic of students' ability and ambiguous personal reference. The results of the previous finding and the analysis were presented based on the topic. In this section, the researcher took three researches.

There are some related researches to this topic. The first is the research which was conducted by Nilawati (2015) entitled Students' Ability of SMAN 1 Sungguminasa in Using Subordinate Conjunction. The result of her research showed that the students of SMAN 1 Sungguminasa had good ability $(78,66)$ in using subordinate conjunctions. It was proved by the mean score of students obtained through the test in the multiple-choice and fill in the blank. The second research is the research which was conducted by Rivai (2008) entitled Reference Analysis on Azia Yezierska's The Fat of the Land. The result of Rivai's research explained the antecedent of the reference items found in the text based on 3 types of reference which are classified by Halliday and Hasan, those are personal, demonstrative, and comparative reference. The last research is the research which was conducted by Darwis (2011) entitled The Analysis of Anaphora and Cataphora in the Novel "Heist Society" by Ally Carter. As the result of Darwis' research, she found that the anaphoric references which are used in the novel are more dominant than cataphoric reference.

The differences between three of the researches above and the research which was conducted by the researchers that he combined those three topics of the research; students' ability from Nilawati, reference in types from Rivai, and reference in terms by Darwis). Furthermore, no one of those three researches above analyzed students' ability towards ambiguity in reference while ambiguity in the written text could be big trouble for the reader to catch where the writer is referring with the pronoun. Considering that reason, the researcher initiated to conduct a research 
entitled Students' Ability in Analyzing Ambiguous Personal Reference in 'Women's Murder Club: The Trial" Novel by James Patterson.

\section{The Concept of Discourse Analysis}

Linguists define discourse as text plus the context in which it appears. Discourse has generally been considered by particular linguists as anything beyond the sentence. A text itself can be interpreted in many ways. Bahaziq (2016:112) stated that language could be interpreted differently depending on the context in which the discourse occurs. The word shooting can be implied at least 3 meanings in 3 different aspects. Shooting in football means someone kicks the ball, shooting in photography means someone filming with a camera, and shooting in military means discharge a bullet from a gun. People use language in many different contexts, and understanding those contexts is necessary to understand what the speaker means. Discourse analysis is the approach of analyzing sign, vocal, and written language in use. As stated by Sutherland (2016:x) that discourse analysis means "the study of language in use". McCarthy in Emmiyati, 2015:1) also states that discourse analysis is the way of describing and understanding how language is used. In short, discourse analysis is the observation of the relationship between the text itself and the context.

\section{Text Concept}

Text is mostly defined as utterances without context. It contrasts with a discourse that is defined as the text within the context. Petkunaite (2013:6) states if every language consists of linguistic units: text, sentence, clause, word, and morpheme. He further added that this means a group of linguistic units cannot form a text if the relation of them is lack of meaning. Halliday \& Hasan (1976:1) use text for the term of discourse. They claimed that "A text may be spoken or written, prose or verse, dialogue or monologue". The collection of words, clauses, and sentences must be tied to each other by meaning to become a text. Sutherland (2016:3) also states that linguists use text to mean "a set of coherent words that present a message". From those definitions, the researchers drew conclusion that text is a set of coherent words that can be speeches by one person (monologue), conversations that include many speakers (dialogue), novel, newspaper, article, journal, and so on which are conveying a message.

\section{Cohesion Concept}

All of the words in the text work together, that is, they are coherent, to create a message bigger than any one word on its own. Petkunaite (2013:6) defined cohesion as it exists within a text. Sutherland (2016:4) states that the first thing to consider when looking at what defines a text is to think about how the words in the text are connected in a way that makes it clear that they belong together. Halliday \& Hasan (1976:6) state that cohesion is a semantic relation (relation of the meaning) between an element in the text and some other elements. They state that the concept of 
cohesion is a semantic relation, it is not a structural relation. Cohesion is a part of the language system. Cohesion is a substantial aspect of discourse analysis. Halliday and Hasan organize this concept by classifying it into two big types of distinct categories: grammatical cohesion and lexical cohesion. Grammatical cohesion category is represented in the text by particular features, those are reference, substitution, conjunction, and ellipsis. As explained above, the researchers focused his research only on one type of four grammatical cohesion types that is: reference.

\section{Theory of Reference}

Petkunaite (2013:11) claims that reference shows something which is said in preceding or succeeding sentence that is creating cohesion. He also added that reference occurs when several elements are linked in order to avoid re-stating the nouns many times. Bahaziq (2016:112) emphasizes that the most used grammatical devices are conjunction and reference. The researchers focus on discussing reference in this research. M. Bloor \& T. Bloor in Bahaziq (2016:113) state that Reference may either be exophoric or endophoric. It is strengthened by the theory from Halliday \& Hasan (1976:31) who distinguish general reference into two special terms those are endophoric reference as a term of reference within the text (textual reference), and exophoric reference as a special term for situational reference (contextual reference).

Further Halliday and Hasan distinguish endophora into two different usages, those are anaphora and cataphora. Those which refer back in the text for the interpretation is called anaphoric reference, and those which refer forward in the text for interpretation is cataphoric reference. Exophoric reference is a reference where the interpretation of a text lies outside the text, in the context of a situation which plays no part in textual cohesion. Exophoric reference contributes to the creation of text by linking the language with the context of the situation, but it does not contribute to the integration of one passage with another. In this research, the researchers limited his research only on one type of two special terms of general reference that is endophora.

Three types of reference are classified by Halliday and Hasan, those are Personal, Demonstrative, and Comparative reference. Considering what has been stated above, it can be concluded that reference is a device that is used for pointing to particular objects. The different reference depends on the placement of the object it refers to, whether it is out of or within the text. Three dominants types of reference are to indicate person, demonstrate and compare object. In this research, the researchers limited his research only in one type of three classifications of reference types that is personal reference.

Benner (2004:1) says that every pronoun should refer clearly and unmistakably to one particular noun and that noun is called as the antecedent. He then emphasizes his statement before saying that a pronoun should have only one antecedent (the noun it refers to). Eggenschwiler \& 
Biggs (2001:28) states that personal pronouns represent person, people or things who have different in forms according to the context. Petkunaite (2013:14) strengthened it that personal reference is one of reference items that indicates something which is being referred to by the usage of person, oriented pronouns or adjectives. Sutherland (2016:7) then lately defines personal references are those which are often used for people.

The category of personal includes three classes of personal pronouns, possessive pronouns, and possessive adjectives. The differentiation in terms of traditional categories of person is that between the first and second person (I, you, we include the objective case of each: me, you, us; possessive adjective; my, your, our; possessive pronoun: mine, yours, ours; possessive adjective: my, your, our) and third person (he, she, it, they, one includes objective case: him, her, it, them, one; possessive adjective: his, her, its, their, one's; possessive pronoun: his, hers, theirs).

\section{Theory of Ambiguous Pronoun}

Rauf (2014:140) argues that people can express their opinion, ambition, willing, or what they feel through language. But language cannot exist without ambiguity because one word itself can have more than one meaning. A word, phrase or sentence is ambiguous when it can be interpreted in more than one meaning. Sennet (2016:3) states that ambiguity is either speech acts or sentences in which the sentences are used. There is no guarantee that every ambiguous sentence will result in any un-clarity regarding what was expressed or meant by the speaker. There is also no guarantee that unambiguous utterances will result in clear understanding either.

Zhang (1998:5) defines ambiguity as expressions that have more than one semantically unrelated meaning. Further, Zhang (1998:8) states that an ambiguous expression has more than one meaning, and they are semantically unrelated. Zhang argues that ambiguity can be eliminated if the ambiguous word occurs in a certain context. Sari (2017:2) states that the importance of studying ambiguity is that to reduce the judgment in which some people are learning the language assess that their friends' interpretation is wrong. Irawan (2009:103) states that the readers will not understand the meaning of the word or sentence if there are too many possible interpretations.

Nuttal (in Puspita, 2017:12) categorized five aspects regarded as difficulties that the students encounter in comprehending a text.

\section{Determining the main idea}

The main idea is a complete statement that the writer tells in the topics. In determining ideas, the students hope that they can comprehend the topics that are told in the texts. The students can find the main idea in a specific location such as the first, the middle or the last sentence of a paragraph but it can give the students difficulties finding the main idea because they are confused to get the main idea of the topics and where the main idea located. 
Rauf and Amanda, Students' Ability in Analyzing...

\section{Finding Specific Information}

Scanning means Seeing quickly through a text to find a particular piece of information in the text. To find out the specific information, the students have to read all of the content of the text. Sometimes the students have difficulties to differentiate between important and unimportant information in the texts.

\section{Making Interference}

The students hope that they will understand what the topic is and they can find the conclusion in making an inference. Therefore, sometimes it gives the students difficulties to make inference because the meaning of the statement is not implied in the text.

\section{Identifying Reference}

Reference is the relationship between a grammatical unit (usually a pronoun). Pronoun refers to another grammatical unit such as noun or noun phrase (Rainbolt and Dwyer in Puspita: 2017). Identifying reference can make the students understand the pronouns in the sentences whether the pronouns are used to show the place, people or situation.

\section{Understanding the Meaning of Word}

Vocabulary is a major component that is fundamental in the reading process for the students. Therefore, unfamiliar vocabularies in the text should be mastered before reading the material so the students can understand the texts.

Based on the theory above, one of the difficulties that may occur in comprehending text is identifying reference. Most people are not conscious about Linguistics which is not considered whether right or wrong. What they must realize is that the way of language is appropriate or not in use. Sagi \& Rips (2014:1) emphasize that statement by saying that readers and listeners who face pronouns are sometimes given antecedents' choices. When the pronouns and the antecedents span separate sentences, two or more antecedents can each produce grammatical discourse, and the reader must use semantic and contextual clues to find out which is right.

Stone (2016:1) also states that "A pronoun takes the place of a noun, but a pronoun must always refer clearly to its antecedent, which is the noun that the pronoun replaces. If the antecedent of the pronoun is unclear, then the sentence will be unclear as well. An ambiguous pronoun occurs when more than one possible antecedent exists". In the conclusion, ambiguity occurs when a word or bigger element can be interpreted to more than one meaning or when the interlocutor or the reader can not directly get the point of what the speaker or the writer is talking about. Getting the real meaning of ambiguity in the written text will be more difficult than getting real meaning in spoken language. If the interlocutor is listening to the speaker and he finds an ambiguous word or sentence, the interlocutor can directly ask about it to the speaker to get feedback. Even more, the 
speaker can support his sentence with body language to make his sentence clearer. The obstacles in written text, both direct feedback and body language cannot be got.

Pronoun error and ambiguous pronoun are different, pronoun error occurs when the pronoun breaks the pronoun agreements where the reference agrees to the antecedent in point of view, number, and gender. For instance:

Tasbih wants to borrow my pen, but I need them too.

In the case of the sentence above, them is the reference and pen is the antecedent. It is called error because pen is singular, while them (reference of pen) is plural. The antecedent and the reference must be matched, if the antecedent is plural, so is the reference. If the antecedent is singular, so is the reference. The correction of the pronoun error above can be:

Tasbih wants to borrow my pen, but I need it too.

The reference and its antecedent are already matched in ambiguous reference. The problem is, the reference can be referred to more than one antecedents. It could give so much confusion for the reader in getting what the writer really meant. Students have been learning personal reference (called as pronoun in most of schools) since elementary school and even the college students learn about this subject, but it is never being explained that how substantial the impact in putting an ambiguous reference item in written text. In reading a novel, if the reader gets a wrong antecedent of the reference item, it will affect the perception of the reader so that misunderstanding about the story will occur. Eggenschwiler \& Biggs (2001:36) gives some other instances for ambiguous pronoun reference as follow:

The counsellor was speaking to Dave, and he looked unhappy.

Eggenschwiler (2001:36) questions that "who looked unhappy in the sentence above? the counsellor or Dave?”. Eggenschwiler then shows the second sentence as follows:

After the girls left the hotel rooms, the maids cleaned them.

Eggenschwiler describes that in the second instance, the reader's good sense tells him or her that the maids cleaned the rooms and didn't clean the girls. According to him, the reader can figure out which antecedent is represented by the pronoun by relying on the context or using a good sense when facing ambiguous personal pronoun. But sometimes in some circumstances, the reader couldn't rely on the context or him or her good sense to help him or her figure out which antecedent is represented by the pronoun. And what about the first sentence? No clue exists as to whether the counsellor or Dave looked unhappy. This theory is emphasized by the statement from Sagi \& Rips (2014:1) in their theory, that the readers who face ambiguous pronouns must use semantic and contextual clues to find out which is right. 
Eggenschwiler \& Biggs (2001:37) gives the solution that the problem above can be solved in various ways, including changing the structure of the sentence or eliminating the pronoun. He added that be sure to read the sentence carefully to make sure that ambiguity is avoided. Irawan (2009:104) also says that ambiguity needs to be thought deeply, exposed and eliminated. Further, it is stated also by Wakhidah (2018:2) that some possible ways to disambiguate ambiguous sentence are by paraphrasing, adding preposition, and using pictures.

\section{METHOD}

The researchers used mixed method in this research. Creswell (2014:43) defines that mixed methods is the combination or integration of quantitative and qualitative research. He added that quantitative data commonly consists of close-ended responses, for instance, a questionnaire. While he defines that qualitative data contains open-ended without prearranged responses. The researchers used quantitative method to show students' scores. As Sugiyono (2013:7) states that the quantitative method is a research method where the data are in the form of numbers and analysis using statistics. Then, the researchers used qualitative method to interpret students' reasons in analyzing the test.

\section{Respondents}

The population of this research were active English and Literature seventh semester students (batch 2016) of State Islamic University of Alauddin Makassar. The researchers used simple purposive sampling by taking 10 students as the sample for this research. As stated by Sugiyono (2013:85) that purposive sampling is the technique of determining the sample with certain considerations where this sample is suitable for qualitative research. The researchers used this type of sampling with the consideration that 7 th semester students have finished their class meetings (subjects). The researchers took 10 respondents only because he gave follow up interview (openended questionnaire) with every single respondent. The researchers wanted to know more about the students' true ability, and the data got by the 10 students already considered sufficient for what the researchers needed.

\section{Instruments}

The researchers applied the instruments to collect the data were both open-ended question and close-ended question (Creswell, 2008: 225). The paper test used by the researchers contained 2 parts, they were close-ended question and open-ended question. The researchers used closeended (multiple choices) to get the students' answers. The researchers also used open-ended to find out the way of the students analyzed the test so the collected data would be more accurate. It 
is in line with the argument from Creswell (2014:239) that in open-ended question, the researchers asking general question the respondents which allows them to provide their views freely.

The researchers applied free response question (Creswell, 2014: 239) to let all respondents deliver their answer freely based on what they think and what they know in which will rise vary answers. The researchers gave the identification text which consists of 14 items which each of them contains ambiguous personal pronoun. The extracts were taken from Women's Murder Club: The Trial novel by James Patterson based on the theory of ambiguous pronoun by Eggenschwiler (2001). The researchers put the extracts randomly. The contents of the test developed by consulting it with the lecturers who are specialists in the related subject.

\section{Procedures}

The test and interview process were done face to face. Before conducting the test and the interview, the researchers firstly asked for the respondent's right time, so then the atmosphere of the interview would be better so that the data obtained will be more complete and accurate, as suggested by Sugiyono (2013:141) that made the researchers held the test and interview at different times for each respondent. The researchers used these following steps in collecting the data by distributing the question sheets to the students, Explaining and giving the instruction for the students to answer the test, and, interpreting all of the collected data.

\section{Data analysis}

The researchers analyzed the data using quantitative and qualitative method. The procedures of data analysis in this research are presented chronologically as follow: The formula to find the individual score of the student:

$$
\begin{array}{ll}
\mathrm{P} 1=\frac{S S}{S M} \times 100 \\
\text { Where: } \\
\text { P1 : } & \text { Percentage of individual score } \\
\text { SS : } & \text { Student's score } \\
\text { SM : } & \text { Maximum score }
\end{array}
$$

(Depdikbud in Alexander, 2013:3)

The used the formula to find the ability of whole students in analyzing ambiguous reference as follows:

$$
\mathrm{M}=\frac{\Sigma X}{N}
$$

Where:

$\begin{array}{lll}\mathrm{M} & : & \text { Mean score of the students } \\ \Sigma X & : & \text { Sum of students score } \\ \mathrm{N} & : & \text { Total of the students }\end{array}$


(Ananda, 2018:72)

The researchers used a formula below to find out the 4 levels of criteria of student's ability:

\begin{tabular}{|c|c|}
\hline The Interval Score & The Criteria \\
\hline $86-100$ & Excellent \\
\hline $76-85$ & Good \\
\hline $56-75$ & Fair \\
\hline $10-55$ & Poor \\
\hline
\end{tabular}

(Nurgiyantoro in Susanti, 2017:5)

\section{FINDINGS AND DISCUSSION}

The results were presented as data descriptions that were taken from 10 students of the seventh semester of English and Literature Department batch 2016. There are 2 types of data that had been applied in this research. The data were taken using multiple choices and fill in the blank. All data from tests 1 and 2 are presented in this part. The students' ability of the seventh-semester student of English and Literature Department batch 2016 in analysing the antecedents of ambiguous personal references in Women's Murder Club: The Trial novel by James Patterson.

The researchers presented the result about students' ability in analyzing ambiguous personal reference found in Women's Murder Club: The Trial novel by James Patterson and the way the students analyzed the extracts. The researchers firstly showed the overall score of the students in a table, then the table was described into some extracts with description. At last, the researchers accumulated the overall score obtained by the students by decreasing some scores of some students due to their wrong reason. The researchers used 2 types of instruments that were multiple choices to ease the students find the possible antecedents, and fill in the blank which was used to get the reason of the students in choosing the antecedents. The reason gave by the students showed the way they analyzed the ambiguous pronoun in each extract.

The researchers used some abbreviations, they are:

E: Extract

R: Respondent

C: Correct

I: Incorrect

\begin{tabular}{|c|c|c|c|c|c|c|c|c|c|c|c|c|c|c|c|}
\hline & E1 & E2 & E3 & E4 & E5 & E6 & E7 & E8 & E9 & E10 & E11 & E12 & E13 & E14 & sCORE \\
\hline R1 & C & C & C & C & C & C & C & C & C & C & C & C & I & C & 92.8 \\
\hline R2 & C & C & I & C & I & I & C & C & C & C & C & C & I & C & 71.4 \\
\hline R3 & C & C & I & C & I & I & C & C & C & C & C & C & I & C & 71.4 \\
\hline R4 & I & C & I & C & I & C & C & I & C & I & C & C & C & C & 64.2 \\
\hline
\end{tabular}




\begin{tabular}{|c|c|c|c|c|c|c|c|c|c|c|c|c|c|c|c|}
\hline R5 & C & C & C & C & C & C & C & I & C & I & C & I & C & C & 78.5 \\
\hline R6 & C & I & C & C & I & I & $\mathrm{C}$ & C & $\mathrm{C}$ & I & C & I & I & C & 57.1 \\
\hline R7 & I & I & I & C & I & I & C & I & C & I & C & I & I & C & 42.8 \\
\hline R8 & I & C & I & C & I & I & I & I & C & I & C & $\mathrm{C}$ & C & I & 50 \\
\hline R9 & I & I & I & C & C & C & I & C & C & I & C & C & C & C & 64.2 \\
\hline R10 & I & C & C & C & I & I & C & C & C & C & C & C & C & C & 78.5 \\
\hline of Correct & $50 \%$ & $80 \%$ & $40 \%$ & $100 \%$ & $30 \%$ & $40 \%$ & $80 \%$ & $60 \%$ & $100 \%$ & $40 \%$ & $100 \%$ & $70 \%$ & $50 \%$ & $100 \%$ & 67.09 \\
\hline
\end{tabular}

Table 1. Score Obtained by the Students

The table shows the overall result of the students' answers whether they answer the correct or incorrect antecedents. The table shows that the ability of the seventh-semester students had fair ability (67.09) in analyzing pronoun in 14 given extracts. By seeing their reasons in choosing their answers, some of the students were detected as guessing (answering the extract correctly but giving wrong reason and even not giving any reason). Then in the preceding, the table is described into some extracts with the reasons of the students who answers the correct antecedents.

Extract 1: Chapter 2, page 7.

"Call came in to 911 about ten minutes ago," Conklin said as we tore up California Street. "A kitchen worker said he recognized Kingfisher out in the bar. He was still trying to convince 911 that it was an emergency when shots were fired inside the club."

From 10 respondents, 5 students chose kitchen worker and the other 5 students chose Kingfisher as the antecedent of the pronoun he in the extract above. It is found that $50 \%$ of respondents refer the pronoun he incorrectly to Kingfisher which means that they are confused by the existence of the ambiguous personal reference he which can refer anaphorically whether to kingfisher or kitchen worker. The respondents had poor ability $(50 \%)$ in analyzing the pronoun he in the extract 1 because their average score in this extract is in the interval between 10-55.

After reading the respondents' reason in choosing the antecedent, the researchers found that the respondents' who answered the correct antecedent, they were R1, R2, R3, R5, and R6. They gave their reasons that previous sentence explained kitchen worker is referred by the pronoun he. Specifically, R1 gave a reason that "he refers to kitchen worker because the one who was trying to convey the incident was kitchen worker'. It can be seen that generally, the respondents analyzed the pronoun he contextually by saying that the incident was conveyed by kitchen worker.

Extract 2: Chapter 2, page 7.

Richie yanked the wheel hard left to avoid an indecisive panel truck, then jerked it hard right and took a turn onto Sansome.

There were 8 students who chose the wheel as the antecedent of it correctly from 10 students in total, the 2 rest of the respondents chose the correct antecedent that is panel truck. The finding shows that $80 \%$ of the student can refer the pronoun it correctly to the wheel where the pronoun it can refer anaphorically whether to the wheel or panel truck. The respondents had good ability 
$(80 \%)$ in analyzing the pronoun it in the extract 2 because their average score in this extract is in the interval between 76-85.

The students who answered the correct antecedents were R1, R2, R3, R4, R5, R7, R8, and $\mathrm{R} 10$. Most of them gave a reason that it refers to the object that is the wheel, so it is the pronoun of the wheel. Specifically, R5 gave a reason that "the first sentence in the extract above shows an action to the wheel'. That reason means that most of the students analyzed the extract 2 contextually by seeing the structure of the text.

There was 1 student who answered the correct antecedent at the extract 2 but gave the incorrect reason, that was R7. The R7 gave the reason for choosing the wheel as the antecedent of the pronoun it was that because the wheel was the subject which would be replaced by the pronoun. It seems that the R7 analyzed the pronoun it in extract 2 through the context. Obviously, the R7 correctly analyzed that the pronoun it refers to the wheel but she was wrong by determining the position of the word the wheel as the subject. As a matter of fact, the wheel in extract 2 stands as an object. R7 seems to need to study more about the classification of pronouns. There were also one student (R3) answered the correct antecedent but didn't gave any reason in choosing the antecedent.

Extract 3: Chapter 4, page 11.

Shooters inside the Vault were using the granite doorframe as a barricade as they leaned out and fired on the uniformed officers positioned behind their car doors.

From 10 respondents in total, 6 of them chose shooters as the antecedent of the pronoun their. As a matter of fact, the correct antecedent is uniformed officers. This result shows that $60 \%$ of the students were confused by the existence of the ambiguous pronoun their where it can refer anaphorically to shooters and uniformed officers. The ability of the respondents in analyzing pronoun their in this extract was fair $(60 \%)$ because their average score is in the interval between 56-75.

Regarding the reason of the students who answer the correct antecedent, that are R1, R5, and R10. Generally, they said that the ones who positioned behind the car were the officers, as stated specifically by the R1 that the shooters used granite doorframe as barricade and the ones who positioned bebind the car were the officers. It means that generally, the students analyze the pronoun their according to the context by saying that the ones who positioned behind the car were the officers.

There was also 1 student who chose the correct antecedent in extract 3 but stated the wrong reason. The student was R5, she stated that the pronoun their refers to officers because of the position of the word "barricade" in the second sentence which stands as a subject from uniformed officers. That analysis was wrong, the subject of the officers in the extract 3 is the pronoun they which refers 
to shooters which stands as the subject. In that case, the researchers assumed that R5 might answer extract 3 by guessing.

Based on the data in findings, the researchers found that the seventh-semester students of English and Literature Department batch 2016 analyzed ambiguous pronoun reference in the given extracts by using 3 ways, they were context, good sense, and guessing. While Eggenschwiler (2001:37) in his theory mentioned two ways only, they are by relying on the context or using a good sense.

As the result, it was found that the students who analyzed the pronoun correctly were the ones who analyzed it by relying on the context and their good sense. It is in line with the statement from Eggenschwiler. According to him (2001:37), the reader can figure out which antecedent is represented by the pronoun by relying on the context or using a good sense when facing ambiguous personal pronoun. This theory is emphasized by Sagi, E., \& Rips, L. J. (2012: 1) that readers and listeners who face pronouns are sometimes given choices of antecedents. When the pronouns and the antecedents span separate sentences, two or more antecedents can each produce grammatical discourse, and the reader must use semantic and contextual clues to find out which is right. On the other hand, it was found that there were students who answered an extract correctly but the student gave the wrong reason and that is determined that the student answered the extract by guessing.

Through this research, the researchers got some other findings from the discussion above, as follow: a. There were 2 students answered the correct antecedent but giving the wrong answer. The factor was because the students were lack of knowledge or a minor understanding of the classification of pronoun whether it is subject or object, b. There was a student answered the correct antecedent but had no idea of the reason for choosing the antecedent, and that is classified as guessing.

The students' score showed that the mean score they got through the test was 67.09, but it could be assumed that their ability is quite below of that score because of the fact found that some students answered the correct antecedent but gave the wrong answer, and another fact that there was student answered the correct antecedent but didn't give any reason of choosing it. That facts prove that the score they obtained doesn't represent accurately their true ability in determining ambiguous personal references in Women's Murder Club: The Trial novel by James Patterson. Based on the fact above, it can be gotten that the accurate ability of the respondents would be decreased from the mean score from 67.09 to 65.2. That result is affected by the reduction score of some students. They were:

a.R5: score 42.8 decreased to 35.7 
b. R7: score 78.5 decreased to 71.4

c. R8: score 50 to decreased to 42.8

As a matter of fact, the reader should not have to struggle in identifying the antecedent of a pronoun. The writer is the one who must make the pronoun reference refer clearly to its antecedent in his writing, he must read his sentences carefully to make sure that he has avoided unclear pronoun reference.

The reader should not have to struggle in identifying the antecedent pronoun. The writer is the one who must make the pronoun reference refer clearly to its antecedent, he must read his sentences carefully to make sure that he has avoided unclear pronoun reference. Some experts had given some ways to resolve that problem. Eggenschwiler (2001:37) himself states that we can solve the ambiguity problem by changing the sentence structure or eliminating the pronoun. The result was in line with Sennet's (2016:3) statement which states that there is no guarantee that every ambiguous sentence will result in any unclarity regarding what was expressed or meant by the speaker. There is also no guarantee that unambiguous utterances will result in full univocal clear understanding either. The result was also in line with the theory stated by Nuttal in Puspita (2017: 12-14) who categorizes that there are five aspects considered as difficulties often faced by students in understanding a text. One of the difficulty is identifying references.

\section{E. CONCLUSION}

The seventh-semester students of English and Literature Department batch 2016 (AG 1-6) had fair ability in analyzing ambiguous reference. It is based on the mean score of the students obtained through the multiple-choice. Their score was 65.2 where it was in the interval between 56-75. It could also be seen that 1 student possessed excellent ability, 2 students got good ability, 5 students belonged to fair ability, and 2 students obtained poor ability. The findings also showed that the respondents gave varied reasons in analyzing ambiguous pronoun reference even though they chose the same answer. From that findings, the researchers also concluded that in analyzing ambiguous personal reference, the respondents answered the extracts in 3 ways, they were by analyzing it contextuality, analyzing it by relying on their good sense, and analyzing it by guessing. The proof that there was a student who answered the extract by guessing, they were R3 and R8 who chose the correct antecedent but had no reason in choosing their answer.

This research is still far from perfect. Besides having many weaknesses, of course, this research has also its own potency compared with the research which was conducted by Nilawati (2015) entitled Students' Ability of SMAN 1 Sungguminasa in Using Subordinate Conjunctions. Nilawati in her research only used quantitative method that was less effective because the 
respondents might have a big potential to answer the questionnaire by guessing. For that reason, the researchers in this research used 2 types of research methodologies that were quantitative and qualitative. The researchers used quantitative method to get students' answer, then he used quantitative method to know the way of the respondents analyzing the extracts. It is not so accurate measuring the students' ability just by seeing their score in statistic, but it is needed to do follow up interviews for getting further information about the respondents' understanding. It could also show whether the student answers the given test with their true ability or not. Relating the findings to the related hadith and Nawawiy's argument in chapter 2 that it is a must to avoid ambiguous things because it will plunge someone into something haram. That is also applicable in using a pronoun reference in writing especially. It is a must to avoid ambiguous pronoun because it will plunge the reader into confusedness in determining the antecedent.

\section{REFERENCES}

Alexander. (2013). Peningkatan Kemampuan Pemecahan Masalab Matematis Melalui Pendekatan Realistik Matematika (RME) Pada Mata Kuliah Statistik Statistik Pendidikan Mabasiswa PGSD Semester V Tahun Akademis 2012/2013, 1-9. https://doi.org/10.1017/CBO9781107415324.004

Almath, D. M. F. (1995). 1001 Hadits Terpilib. (K. Iffa, Ed.) (9th ed.). Jakarta: Gema Insani Press.

Ananda, R. (2018). Statistika Pendidikan: Teori dan Praktik Dalam Pendidikan. Journal of Visual Languages \& Computing, CV. Widya Puspita (Vol. 11).

Bahaziq, A. (2016). Cohesive Devices in Written Discourse: A Discourse Analysis of a Student's Essay Writing. English Language Teaching, 9 (7), 112. https://doi.org/10.5539/elt.v9n7p112

Benner, M. L. (2004). Faulty Pronoun Reference - Exercise 4. Writing. Retrieved from https://webapps.towson.edu/ows/proref.htm

Creswell, J. W. (2008). Research Design: Qualitative, Quantitative, and Mixed Method Approaches. (V. Knight, Ed.) (3rd ed.). California: SAGE Publications.

Creswell, J. W. (2014). Research Design: Qualitative, Quantitative, and Mixed Methods Approaches. (V. Knight, Ed.) (4th ed.). California: SAGE Publications.

Darwis, A. (2011). The Analysis of Anaphora and Cataphora in the Novel "Heist Society" by Ally Carter (A Discourse Analysis). UIN Alauddin Makassar.

Eggenschwiler, J., \& Biggs, E. D. (2001). Writing: Grammar, Usage, and Style. (H. Gelman, Ed.). New York: Hungry Minds.

Emmiyati, N. (2015). Discourse Analysis. Makassar.

Hadith Commentary. (2014). Hadith 6. Avoiding Doubtful Matters. 
Rauf and Amanda, Students' Ability in Analyzing...

https://hadithcommentary.com/nawawi/hadith6/

Halliday, M. A. K., \& Hasan, K. (1976). Cohesion in English. Cohesion in English, 1-374. https://doi.org/10.4324/9781315836010

Irawan, W. B. (2009). An Analysis of Ambiguity in the Articles of the Jakarta Post. Universitas Sebelas Maret.

Nilawati, A. (2015). Students' Ability of SMAN 1 Sungguminasa in Using Subordinate Conjunction. State Islamic University of Alauddin Makassar.

Patterson, J. (2016). Women's Murder Club: The Trial. London: BookShots.

Petkunaite, E. (2013). Reference as a Grammatical Cohesive Device in Science Research Articles. Siauliai University.

Puspita, A. (2017). Student's Difficulties in Comprehending English Reading Text at Second Grade Student of SMA N 2 Metro. University of Lampung.

Rauf, M. (2014). Polite Expressions Used By Teachers in Teaching English. Journal UIN Alauddin, 3(9), 139-157. Retrieved from http://journal.uinalauddin.ac.id/index.php/elite/article/view/3388

Rivai, A. (2008). References Analysis on Anzia Yezierska's The Fat of The Land. State Islamic University Jakarta.

Sagi, E., \& Rips, L. J. (2014). Identity, causality, and pronoun ambiguity. Topics in Cognitive Science, 6(4), 663-680. https://doi.org/10.1111/tops.12105

Sari, I. P. (2017). Analisa Makna Ambigu pada Naskah Drama Karya William Shakespeare 'A Midsummer Night's Dream.' State Islamic University of Maulana Malik Ibrahim Malang.

Sennet, A. (2016). Ambiguity", The Stanford Encyclopedia of Philosophy. Retrieved from https://plato.stanford.edu/archives/spr2016/entries/ambiguity/

Stone, M. (2016). What is an Ambiguous Pronoun? - Definition, Structure \& Example - Video \& Lesson Transcript. Retrieved from https://study.com/ academy/lesson/what-is-an-organogramdefinition-structure-example.html

Sugiyono. (2013). Metode Penelitian Kuantitatif Kualitatif dan R\&D. Journal of Chemical Information and Modeling (Vol. 53). Bandung: Alfabeta. https://doi.org/10.1017/CBO9781107415324.004

Susanti, L., Kurniaman, O., \& Antosa, Z. (2017). An Analysis of Ability in Understanding Reading Discourse of Students Class V SD Negeri Se-Gugus III Sail Sub-District Pekanbaru City. (Journal). Pekanbaru: University of Riau.

Sutherland, S. (2016). A Beginner's Guide to Discourse Analysis. London: Palgrave.

Wakhidah, N. J. I. (2018). A Study of Ambiguity Found in Students' English Workbook of Vocational High School, 1(1), 1-15. https://doi.org/10. 1016/j.worlddev.2018.08.012 
Volume 6, Number 02, December 2020

Zhang, Q. (1998). Fuzziness - vagueness - generality - ambiguity. Journal of Pragmatics, 29(1), 13-31. https://doi.org/10.1016/s0378-2166(97)00014-3 